\title{
Szkice
}

\section{Historia środowiskowa Zagłady}

Jacek Małczyński

TEKSTY DRUGIE 2017, NR 2, S. 17-33

DOI: $10.18318 /$ td.2017.2.2

Załóż,że trzęsienie ziemi niszczy nie tylko życie, budowle, przedmioty, lecz również narzędzia, które służą do bezpośredniego i pośredniego mierzenia trzęsień ziemi. Niemożliwość zmierzenia nie dość, że nie wyklucza w ocalałych myśli o wielkiej sile sejsmicznej, to jeszcze tę myśl pobudza.

Jean-François Lyotard

W przywołanym jako motto fragmencie z Poróżnienia Jean-François Lyotard porównuje Zagładę do trzęsienia ziemi o tak wielkiej mocy, że zniszczone zostały wszelkie sejsmografy mogące służyć do oszacowania skali zniszczeń1. Porównanie to zyskało sławę i było często przywoływane w kontekście dyskusji na temat możliwości reprezentacji Zagłady, które zdominowały studia na jej temat. W ciągu ostatnich dekad powstały liczne prace poświęcone tej problematyce. Ukazało się również wiele
Jacek Małczyński -

adiunkt $w$ Instytucie

Kulturoznawstwa

UWr, członek zespołu

Laboratorium Humanistyki Współczesnej. Autor pracy doktorskiej Krajobrazy Zagłady. Przyroda w przedstawieniach i miejscach pamięci Holocaustu. Współredaktor tomu Kultura nie-ludzka (2015).

Obecnie interesuje się problem pamięci o Zagładzie w kontekście antropocenu. Kontakt: jacek. malczynski@uwr. edu.pl

1 J.-F. Lyotard Poróżnienie, przeł. B. Banasiak, Wydawnictwo UJ, Kraków 2010, s. 69. 
opracowań odsłaniających polityczny, społeczny i kulturowy wymiar Zagłady. Aspekt środowiskowy nazistowskiego ludobójstwa nie został jednak dotychczas dostatecznie zbadany ${ }^{2}$. W tekście tym postuluję otwarcie się studiów nad Zagładą na historię środowiskową i ich włączenie w toczące się aktualnie debaty na temat zmian klimatu, zrównoważonego rozwoju, wymierania gatunków, klęsk ekologicznych czy migracji klimatycznych.

Proponuję zatem, aby poczynione przez Lyotarda porównanie Zagłady do trzęsienia ziemi potraktować dosłownie. Biorąc pod uwagę toczące się aktualnie dyskusje na temat nowej ery geologicznej w dziejach Ziemi, nazywanej roboczo antropocenem ${ }^{3}$, nabiera ono moim zdaniem nowego znaczenia. Według Dipesha Chakrabarty'ego nastanie antropocenu oznacza kres nowoczesnego podziału na historię naturalną i ludzką. Człowiek przestaje być już tylko czynnikiem biologicznym i staje się siłą geologiczną ${ }^{4}$.W antropocenie

2 Stwierdzenie to odnosi się nie tylko do Zagłady, lecz także do Il wojny światowej w ogóle. Na deficyt badań nad środowiskowym wymiarem wojny zwracał uwagę w 2003 roku J.R. McNeill (Observations on the Nature and Culture of Environmental History, "History and Theory" 2003 Vol.. 42). Sytuacja ta zaczęła zmieniać się w ostatnich latach. W opublikowanym w 2013 roku artykule Environmental Dimensions of World War II J.D. Hamblina można odnaleźć odniesienia do licznych prac na temat relacji między wojną a środowiskiem. Mimo to, jak zauważa Hamblin: „Badacze wojny rzadko patrzą na nią przez środowiskowe soczewki, a historycy środowiska zajmują się głównie zmianami w środowisku w czasie pokoju". Autor przedstawia szereg problemów badawczych, z którymi powinna zmierzyć się historia środowiskowa wojny, takich jak: wpływ działań wojennych na środowisko naturalne (np. zniszczenia spowodowane bombardowaniami, wylesienie, eksploatacja zasobów naturalnych, przekształcenia krajobrazu związane z budową fortyfikacji itp.); możliwości i ograniczenia w prowadzeniu działań wojennych spowodowane czynnikami środowiskowymi (np. topografia, warunki klimatyczne, występowanie chorób, dostęp do zasobów naturalnych itd.); a także znaczenia przypisywane przyrodzie w rywalizujących ze sobą ideologiach. Hamblin wskazuje również na wpływ, jaki II wojna światowa wywarła na rozwój świadomości ekologicznej w okresie powojennym. J.D. Hamblin Environmental dimensions of World War II, w: A companion to World War II, t. 2, ed. by T.W. Zeiler, D.M. DuBois, Willey-Blackwell, Malden 2013, s. 698-716.

3 Termin ten stał się popularny po 2000 roku, kiedy Paul Crutzen, chemik i badacz atmosfery, zaproponował, by okres ostatnich 200 lat w dziejach Ziemi związany z industrializacją, urbanizacją oraz emisją gazów cieplarnianych do atmosfery na niespotykaną wcześniej skalę nazwać antropocenem. Od tego czasu trwają dyskusje na temat datacji i nazwy nowej epoki (pojawiły się terminy oboczne, takie jak "kapitałocen" czy "chtulocen"). Chociaż w dyskusjach antropocen łączy się zazwyczaj ze zmianami klimatycznymi i globalnym ociepleniem, specjalna komisja (Grupa Robocza ds. Antropocenu) ogłosiła na Międzynarodowym Kongresie Geologicznym w 2016 roku, że nowa epoka rozpoczęła się po II wojnie światowej na skutek testów broni atomowej.

4 D. Chakrabarty Klimat historii. Cztery tezy, przeł. M. Szcześniak, „Teksty Drugie” 2014 nr 5, S. 179. 
nie można pisać historii Ziemi, nie uwzględniając sprawczości człowieka. Jakie ma to konsekwencje dla studiów nad Zagładą? Myślenie w kategoriach antropocenu oznacza radykalną zmianę perspektywy czasowej. Dokonujący się współcześnie w humanistyce „zwrot geologiczny” powoduje powrót do kategorii „długiego trwania” oraz zainteresowanie „historią głęboką"5. Miarą czasu stają się nie dziesiątki czy setki, lecz tysiące, a nawet miliony lat. Dla badań nad Zagładą oznacza to uwzględnienie nie tylko jej społecznych i kulturowych konsekwencji, lecz również długotrwałych zmian w środowisku, jakie mogła ona spowodować.

\section{Historia środowiskowa Zagłady}

Katastrofy, zarówno naturalne (epidemie, pożary, wybuchy wulkanów, powodzie itp.), jak i spowodowane działalnością człowieka (np. wylesienie, globalne ocieplenie) stanowią jeden z głównych obszarów zainteresowania historii środowiskowej. Włączenie Zagłady w jej pole tematyczne jest zatem naturalną koleją rzeczy. J. Donald Hughes zdefiniował ogólnie historię środowiskową jako „rodzaj historii, który próbuje zrozumieć to, jak istoty ludzkie żyły, działały i myślały w relacji do reszty natury poprzez zmiany następujące w czasie"'. Biorąc pod uwagę zarysowane przez Hughesa trzy obszary tematyczne, jakimi się ona zajmuje, chciałbym naszkicować jej pole badawcze w kontekście Zagłady. Historia środowiskowa Zagłady bada relacje zachodzące w środowisku między czynnikami ludzkimi i nie-ludzkimi (np. roślinami, zwierzętami, klimatem, pogodą, ukształtowaniem terenu, zarazkami

5 E. Domańska Historia w epoce antropocenu, w: P. Boucheron, P. Gradvohl Spotkanie ze światem II. Dialog polsko-francuski, przeł. E. Brzozowska,Wydawnictwa UW, Warszawa 2015.

6 Historia naturalna i ludzka splatają się ze sobą w powieści Płomyki pamięci Anne Michaels, której bohaterem jest Jacob jako dziecko ocalony z Zagłady przez greckiego geologa Atosa. Jak pisze C. Coussens, w książce tej „fuzja geokulturowej i poetyckiej narracji jest przykładem odkopywania historii Ziemi razem z wnikaniem w naturę indywidualnej i kulturowej pamięci". C. Coussens Secrets of the Earth: Geology and memory in Anne Michales's fugitive pieces, "Annals of the University of Craiova, Series: Philology" 2010, Year XI, No. 2, s. 73-87. A. Michaels Płomyki pamięci, przeł. B. Malarecka, Rebis, Poznań 2000. Po pojęcie "pryzmy" pochodzące z geologii sięga w swojej koncepcji "nie-miejsca pamięci" Roma Sendyka. Pryzma - jak pisze - to "obszar sedymentacji wytworzony z materiałów usuniętych siłą tarcia większych płyt tektonicznych przesuwających się wobec siebie, przemieszczony i pozostawiony $\mathrm{w}$ formie klina tam, gdzie ruchy tektoniczne się zatrzymały". R. Sendyka Pryzma - zrozumieć nie-miejsce pamięci, "Teksty Drugie" $2013 \mathrm{nr} 1 / 2$, s. 335-336. 
itd.). Po pierwsze, zajmuje się ona wpływem środowiska na przebieg Zagłady (np. znaczenie warunków naturalnych w lokalizowaniu oraz funkcjonowaniu obozów, wpływ klimatu i pogody na życie więźniów w obozach i gettach, wykorzystanie przyrody jako narzędzia zbrodni). Po drugie, bada wpływ Zagłady na środowisko (np. skutki funkcjonowania obozów i gett dla środowiska, zmiany w środowisku spowodowane nagromadzeniem szczątków ludzkich, wpływ praktyk memoratywnych na środowisko) ${ }^{\mathbf{8}}$. Po trzecie, interesuje się rozmaitymi wyobrażeniami, znaczeniami i wartościami związanymi z przyrodą w kontekście Zagłady (np. sposoby przedstawiania przyrody w relacjach ocalałych, rola krajobrazu w imperialnej polityce Trzeciej Rzeszy, reprezentacje krajobrazu w sztuce współczesnej podejmującej temat Zagłady) ${ }^{\mathbf{9}}$. Historia środowiskowa Zagłady splata ze sobą wątki z zakresu geologii, archeologii, geografii, biologii, ekologii, historii, socjologii, literaturoznawstwa, kulturoznawstwa i innych dziedzin wiedzy. Jest spokrewniona z takimi nurtami jak posthumanistyka, humanistyka ekologiczna, ekokrytyka, studia nad zwierzętami, roślinami, krajobrazem itp. ${ }^{10}$

8 Badania dotyczące zmian w środowisku spowodowanych przez masowe groby prowadzi Józef Żychowski Wpływ masowych grobów z l ill wojny światowej na środowisko przyrodnicze, Wydawnictwo Naukowe Akademii Pedagogicznej, Kraków 2008. Na temat wpływu obozów śmierci na środowisko zob. M. Smykowski Eksterminacja przyrody w Lesie Rzuchowskim, w niniejszym numerze „Tekstów Drugich". Na kwestie ekologiczne związane z miejscami pamięci Holokaustu jako pierwsi zwrócili uwagę A. Charlesworth, M. Addis Memorialization and the ecological landscapes of Holocaust sites: the cases of Plaszow and Auschwitz-Birkenau, "Landscape Research" 2002 Vol. 27, s. 229-251. O roli krajobrazu w praktykach memoratywnych zob. J. Małczyński Drzewa "żywe pomniki" w Muzeum-Miejscu Pamięci w Bełżcu („Teksty Drugie” 2009 nr 1/2) oraz J. Małczyński Polityka naturywAuschwitz-Birkenau, "Teksty Drugie" 2014 nr 5. Na ten temat zob. także J. Rapson Fencing in and weeding out: curating nature at former nazi noncentration camp sites and mass graves in Europe (w: Emerging landscapes. Between production and representation, ed. by K. Kamvasinou, E. Shinkle, D. Deriu, Ashgate, Farnham, Surrey, Burlington, Vermont 2014, s. 161-171) oraz J. Rapson Topographies of suffering. Buchenwald, Babilar, Lidice (Berghahn, New York 2015).

9 Tematom i metaforom zwierzęcym w literaturze Zagłady poświęcona jest pionierska praca Piotra Krupińskiego „Dlaczego gęsi krzyczały? Zwierzęta i Zagłada w literaturze polskiej XX i XXI wieku, Wydawnictwo IBL PAN, Warszawa 2016.

Narzędzia ekokrytyki do badania literatury Zagłady wykorzystuje A. Ubertowska „Kamienie niepokoją się i staja się agresywne". Holocaust w świetle ekokrytyki, (Po Zagładzie. Narracje postkatastroficzne), „Poznańskie Studia Polonistyczne. Seria Literacka” 2005, t. 25. Zob. także rozdział Rachela Auerbach opłakuje ślady, resztki, widma, wyrwy w ziemi w: A. Ubertowska Holokaust. Auto(tanato)grafie, Wydawnictwo IBL PAN, Warszawa 2014. Krytycznie w stosunku do łączenia studiów nad Zagładą z niektórymi odmianami posthumanistyki odnosi się Joanna Tokarska-Bakir. Jej zdaniem postulaty porzucenia kategorii traumy, pamięci czy empatii stanowią regres. Jak pisze: „Powszechnie artykułowane «zmęczenie traumą» stanowi zaproszenie, by 
Początki historii środowiskowej datuje się na lata 6o. XX wieku i łączy z jednej strony z zainteresowaniem geografią wśród historyków z kręgu francuskiej szkoły Annales, z drugiej zaś z działalnością ruchów ekologicznych w Stanach Zjednoczonych" ${ }^{11}$. Historia środowiskowa nie jest dyscypliną jednorodną. W jej obrębie można spotkać się zarówno z determinizmem przyrodniczym wyjaśniającym ludzkie zachowania poprzez wskazywanie ich przyrodniczych uwarunkowań, jak i podejściem humanistycznym badającym wpływ człowieka na środowisko. Współcześnie historycy środowiska podejmują próby wykroczenia poza dychotomię natura - kultura. Prezentują bardziej kompleksowe i dynamiczne ujęcia niż w latach 70. i 8o. XX wieku, podkreślające wzajemne interakcje i wpisujące się w popularne ostatnio w różnych dyscyplinach humanistycznych badania relacji między tym, co ludzkie i nie-ludzkie, organiczne i nie-organiczne, żywe i martwe. Nowa historia środowiskowa zakłada współzależność i współistnienie człowieka i środowiska: człowiek stanowi część natury i oddziałuje na środowisko, w którym żyje, podobnie jak środowisko wpływa na sposoby życia ludzi. Jak pisze Tim Ingold:

Historia środowiska jest historią działań wszystkich organizmów - ludzkich i nieludzkich, współczesnych i przeszłych - które przyczyniły się do jego powstania. Powinniśmy więc porównywać środowisko nie do pojemnika lub kurtyny, w którym albo za którą toczy się życie, lecz raczej do rzeźby lub pomnika, z uwzględnieniem dwóch okoliczności: po pierwsze, środowisko nie jest kształtowane ręką jednego twórcy, lecz wielu; po drugie, akt twórczy nigdy się nie kończy. ${ }^{12}$

Z kolei Richard C. Foltz, jeden ze współczesnych przedstawicieli historii środowiskowej, zauważa, że:

Historycy świata [...] w swoich pracach wciąż koncentrują się niemal wyłącznie na interakcjach i połączeniach między ludźmi. A przecież powinniśmy pamiętać, że ludzie wchodzą w interakcje nie tylko ze sobą

powróciły wszystkie problemy, których zbadanie przestało być dla nas pilne", J. Tokarska-Bakir Książka wyjścia, „Poznańskie Studia Polonistyczne. Seria Literacka” 2005 t. 25, s. 68.

11 K. Blouin Environmental history, w: The Encyklopedia of Ancient History, ed. by R.S. Bagnall et al., Wiley-Blackwell, Malden, Oxford 2012, s. 2422-2424. 
nawzajem, lecz również - wszędzie i zawsze - ze światem nie-ludzi. Wszelkie działania człowieka zachodzą w kontekście ekosystemów, które w różnym miejscu i czasie mają na nie najróżniejszy wpływ..$^{13}$

Tradycyjna historia świata opiera się na fragmentarycznym modelu wiedzy, który rozdzielnie traktuje różnego rodzaju zjawiska. Wyzwanie, przed jakim stoją dziś badacze przeszłości, polega na tym, by na nowo połączyć ze sobą historię ludzi i środowiska. Foltz nie ma wątpliwości co do tego, że przyroda ma moc sprawczą i wpływa na bieg dziejów. Historycy jednak zazwyczaj tego nie dostrzegają, ponieważ przeceniają w swych pracach sprawczość człowieka i jego znaczenie w przyrodzie. Postulowana historia środowiska skupia się zatem na interakcjach i powiązaniach, ma również potencjał krytyczny i etyczny przejawiający się w postulacie ratowania planety.

\section{Środowisko Zagłady}

Wpływ środowiska na Zagładę można rozpatrywać w kilku aspektach. Położenie geograficzne, ukształtowanie terenu czy dostęp do zasobów były czynnikami, które brano pod uwagę przy lokalizacji obozów. Na przykład obozy w Bełżcu, Chełmnie nad Nerem czy Sobiborze zostały umiejscowione w lesie stanowiącym naturalną zasłonę zbrodni. Insekty i wywoływane przez nie epidemie, zarówno w obozach, jak i gettach, zmniejszały szansę ofiar na przeżycie, stając się współsprawcami Zagłady ${ }^{14}$. Od przyrody zależały również losy Żydów ukrywających się w lasach ${ }^{15}$. We wspomnieniach ocalałych można odnaleźć liczne fragmenty świadczące o tym, że przyroda nie była biernym tłem, na którym rozgrywały się wydarzenia, lecz miała swoistą moc sprawczą ${ }^{16}$. Jako przykład można przywołać fragment opowiadania Zenge-

13 R.C. Foltz Czy przyroda jest sprawcza w znaczeniu historycznym?, przeł. A. Czarnacka, w: Teoria wiedzy o przeszłości na tle współczesnej humanistyki, red. E. Domańska, Wydawnictwo Poznańskie, Poznań 2010, s. 633.

Zob. np. tekst Jacka Leociaka o problemach ze śmieciami w getcie warszawskim (Góry śmieci otulały wata smrodu wszystko, co żyło. Śmieci w getcie warszawskim w perspektywie środowiskowej historii Zagłady, w niniejszym numerze „Tekstów Drugich").

15 T. Cole „Przyroda nam pomagała”. Lasy, drzewa i historie środowiskowe Holocaustu, przeł. K. Dix, w niniejszym numerze "Tekstów Drugich".

16 Pisałem o tym w artykule Krajobrazy Zagłady w perspektywie posthumanistycznej, "Historyka. Studia Metodologiczne" 2015 t. 45. W kolejnym akapicie streszczam niektóre wątki w nim podjęte. 
rin Zofii Posmysz opisujący pracę więźniarek należących do karnej kompanii w Budach (jednego z podobozów Auschwitz-Birkenau) przy osuszaniu okolicznych stawów:

W tych to stawach, zapuszczonych teraz, zarośniętych sitowiem, taplałyśmy się już drugi tydzień. Pogoda była chłodna, nie czerwcowa. Do głodu dołączyła się katusza zimna. Brodziło się w wodzie nieraz do pasa, podkasywanie pasiaka i koszuli niewiele pomagało, pod koniec dnia i tak wszystko było mokre. Oczywista, przez noc nie wysychało. Co rano, wdziewając sztywny jak skóra pasiak, pocieszałyśmy się myślą, że może dzisiaj poślą nas do innej roboty. Lub że pokaże się słońce. Ani jedno, ani drugie się nie spełniało. Następował apel, ze szczękaniem zębów, po tym wymarsz i nieuchronnie zimna woda, w którą trzeba było wejść, całodzienne babranie się w mule, ostre trawy zostawiające krwawe pręgi na ramionach, na nogach, insekty wodne przesycające się do ranek. I świadomość, że nic się nie zmieni. Ani jutro, ani za tydzień, nigdy. Nigdy nie będzie słońca, nigdy nie zaznamy suchości. ${ }^{17}$

Analiza przywołanego fragmentu pozwala uchwycić to, w jaki sposób czynniki nie-ludzkie (pogoda i związane z nią poczucie zimna, mulaste dno stawów, insekty) wpływały na życie więźniarek. Podobnie jednym z toposów stale powracających we wspomnieniach z Auschwitz jest dokuczliwe błoto. Halina Birenbaum tak opisuje swe pierwsze wrażenia po przybyciu do obozu:

Obszar o wiele większy niż na Majdanku, ogrodzony drutami kolczasty$\mathrm{mi}$, wieże wartownicze w niewielkiej od siebie odległości i wyzierające $\mathrm{z}$ nich lufy karabinów maszynowych; długie rzędy murowanych, ponurych baraków, wszędzie dookoła gęste cuchnące błoto... ${ }^{18}$

Chociaż w ostatnich latach ukazało się wiele prac dotyczących literatury wspomnieniowej będącej zapisem doświadczeń obozowych, nie uwzględnia się w nich wpływu, jaki na życie więźniów miały warunki naturalne. Tymczasem, jak wynika z opracowania opublikowanego w 1946 roku na łamach

17 Z. Posmysz Zengerin, w: tejże Ten sam doktor M., Iskry, Warszawa 1981, s. 13-14.

18 H. Birenbaum Nadzieja umiera ostatnia. Wyprawa w przeszłość. Polska 1986, Państwowe Muzeum Auschwitz-Birkenau, Oświęcim 2001, s. 116. 
„Biuletynu Głównej Komisji Badania Zbrodni Hitlerowskich w Polsce”, odgrywały one istotną rolę. W świetle opinii geografa Eugeniusza Romera położenie Oświęcimia w widłach Soły i Wisły, na dnie płaskiej niecki, sprawia, że kraina ta jest naznaczona „piętnem wilgoci, mgły i błota”. Jak wyjaśnia Romer, dzieje się tak za sprawą grubych na 6o-80 metrów, nieprzepuszczających wody pokładów iłów pochodzących z epoki miocenu. Ich nagromadzenie powoduje, że znajdujące się powyżej warstwy żwiru i piasku są wiecznie mokre:

Woda ta przejmuje wszystkie ścieki życia organicznego, stagnując ulega zakażeniu, a tok zakażenia, przesiąkającego ziemię i parującego w powietrze, staje się dla ludzi plagą, której kres mogą położyć tylko kosztowne roboty melioracyjne. $Z$ tych wszystkich przyczyn Oświęcim i jego okolica jest krainą nie tylko wilgoci, ale także malarii i innych chorób, krainą zapadłą i ciężko przez przyrodę upośledzoną. ${ }^{19}$

Dokuczliwe błoto, które tak często powraca w relacjach świadków, stanowiło zatem efekt ulokowania obozu na podmokłych terenach. Z tego samego powodu woda w obozie nie nadawała się do picia, z czego Niemcy zdawali sobie sprawę. W 1941 roku Ferdinand Zunker, profesor Uniwersytetu Wrocławskiego, przeprowadził badania, w wyniku których zabroniono SS-Mannom nie tylko picia tej wody, lecz również płukania nią ust i zmywania w niej naczyń ${ }^{20}$. Na podstawie przygotowanej przez Zunkera ekspertyzy przygotowano plan zakładający osuszenie całego terenu, uregulowanie koryta Soły iWisły oraz stworzenie sprawnego systemu melioracyjnego. W pracach nad realizacją tych projektów brali udział więźniowie obozu w Auschwitz. Mimo że motyw tonięcia w błocie, a także licznych chorób nękających więźniów często pojawiają się we wspomnieniach obozowych, w literaturze na ten temat trudno odnaleźć odwołania do ekspertyz Zunkera czy Romera. Spowodowane jest to tym,że - jak się przyjmuje - warunki naturalne wynikające z ukształtowania powierzchni, występującego na danym obszarze klimatu czy roślinności nie są przedmiotem zainteresowania humanistów.

Osobną kwestię stanowi to, jak środowisko przyczyniło się do wybuchu II wojny światowej. Jak wiadomo, imperializm i kolonializm mają również

Opinia ta zostaje przywołana w: J. Sehn Obóz koncentracyjny Auschwitz-Birkenau, „Biuletyn Głównej Komisji Badania Zbrodni Hitlerowskich w Polsce" 1946t. 1. 
środowiskowy wymiar ${ }^{21}$. W książce zatytułowanej Wojny klimatyczne. Za co będziemy zabijać w XXI wieku Harald Welzer, analizując współczesne konflikty (m.in. w Sudanie i Darfurze), dowodzi, że czynniki środowiskowe są zazwyczaj pomijane przez historyków, którzy uprzywilejowują w swych interpretacjach kwestie etniczne, gospodarcze, społeczne czy polityczne: „Czynniki ekologiczne, demograficzne i geograficzne wciąż są wyraźnie niedocenione w badaniach nad przemocą i ludobójstwem i często po prostu przyporządkowane do kategorii «ideologia». Tymczasem to właśnie odczuwane problemy i ich zakładane przyczyny grają decydującą rolę w perspektywie aktorów działań"22. Zdaniem Welzera przypadki Rwandy i Darfuru stanowią preludium do tytułowych wojen klimatycznych. Nawiedzające Afrykę susze, postępujące pustynnienie, wyczerpywanie się zasobów, wzrost liczby ludności będą prowadzić do nowych „wędrówek ludu” i stanowić źródło kolejnych wojen ${ }^{23}$.Timothy Snyder w książce Czarna ziemia. Holokaust jako ostrzeżenie nie tylko na nowo przeanalizował kontekst polityczny, społeczny i ekonomiczny, w jakim wydarzyła się Zagłada, lecz również wskazał na znaczenie aspektu środowiskowego. Po przegranej I wojnie światowej i utracie zamorskich kolonii Niemcy stracili dostęp do części zasobów naturalnych. Pojawiły się zatem obawy, czy są w stanie samodzielnie zapewnić sobie zapasy żywności oraz rozwijać się i konkurować gospodarczo z Wielką Brytanią czy Stanami Zjednoczonymi. Tę „ekologiczną panikę” w swej polityce skutecznie wykorzystał Hitler, obarczając Żydów winą za zaistniałą sytuację . Jak przypomina Snyder, termin Lebensraum stanowił w języku niemieckim odpowiednik francuskiego biotope i oznaczał siedlisko, tzn. „domenę, którą trzeba kontrolować,

21 Na temat związków między imperializmem i środowiskiem zob. A.W. Crosby Imperializm ekologiczny. Biologiczna ekspansja Europy 900-1900, przeł. M. Kowalczuk, PIW, Warszawa 1999. Polityczna, Warszawa 2010. mines and the Making of the Third World (Verso, London-New York 2001). Davis stawia w niej tezę, że "«Trzeci świat», czyli podział ludzkości na posiadaczy i nędzarzy został ukształtowany pod koniec XIX w. przez zgubne współdziałanie klimatu z gospodarką światową". El Niño to nazwa zjawiska pogodowego powstającego na skutek zmiany ciśnienia atmosferycznego i temperatury Oceanu Spokojnego. Szacuje się, że w drugiej połowie XIX wieku na skutek suszy, powodzi, głodu i epidemii zginęło od 30 do 50 mln ludzi, głównie w Chinach i Indiach. Zdaniem Davisa za katastrofę odpowiedzialne jest zarówno El Niño, jak i europejskie mocarstwa (zwłaszcza Wielka Brytania), które uzależniły od siebie lokalne gospodarki. M. Davis Wiktoriańskie ludobójstwo i korzenie Trzeciego Świata, przeł. M. Turowski, „Lewą Nogą" 2005 nr 17, s. 245. 
by przetrwać fizycznie"24. Funkcję dawnych kolonii w Afryce miały przejąć ziemie na Wschodzie Europy, które miały zagwarantować Rzeszy gospodarczą niezależnośćc ${ }^{25}$. Tereny te były określane przez niemieckich planistów w czasie wojny jako „totale Planungsfreheit”, czyli całkowicie przekształcalne ${ }^{26}$. Germanizacja przyłączonych do Rzeszy terenów pociągała za sobą konieczność przesiedlenia dotychczasowych mieszkańców. W tym sensie Zagładę można postrzegać jako „efekt uboczny” owych planów. Kwestie etniczne, społeczne, polityczne i kulturowe należy zatem połączyć z problemami środowiskowymi.

\section{Środowisko po Zagładzie}

Historyczny przegląd obrazów ludobójstwa dokonany przez Bena Kiernana, który obejmuje przedstawienia oblężenia Kartaginy przez Rzymian, rzezi Azteków dokonanej przez Hiszpanów, eksterminacji Aborygenów w Australii, japońskiego najazdu na Koreę pod koniec XVI wieku czy powieszonych na ulicach Istambułu Ormian, kończy się zdjęciami satelitarnymi pokazującymi zmiany w roślinności, jakie nastąpiły po ludobójstwie w Rwandzie. Na zdjęciu widzimy czerwone plamy oznaczające miejsca po spalonych przez Hutu lasach, w których ukrywali się Tutsi. Kiernan zamieszcza w swej pracy również dwa zdjęcia przedstawiające zmiany, jakie zaszły w krajobrazie w wyniku konfliktu w Darfurze. Wykonana w 2003 roku fotografia pokazuje, że wraz ze zniknięciem miejscowej ludności, a razem z nią zwierząt hodowlanych, powierzchnie uprawne zamieniły się w pustkowia. Kolejne zdjęcie, wykonane trzy lata później, pokazuje, że opuszczone przez ludzi tereny pokryła warstwa roślinności ${ }^{27}$. W jaki sposób Zagłada wpłynęła na środowisko?

24 T. Snyder Czarna ziemia. Holocaust jako ostrzeżenie, przeł. B. Pietrzyk, Znak Horyzont, Kraków 2015, s. 422.

25 Ukazało się kilka prac wskazujących na związki między niemieckim kolonializmem a ekspansją na Wschód w czasie II wojny światowej. Zob. np. J. Zimmerer Colonialism and the Holocaust. Towards an archeology of Genocide, trans. A.H. Beattie, w: Genocide and settler society. Frontier violence and stolen indigenous Children in Australian History, ed. by A. Dirk Mosses, Berghahn Books, New York 2004; W. Sandler "Here Too Lies Our Lebensraum". Colonial space as German space, w: Heimat, region and empire. Spatial identities under National Socialism, ed. by C.-C.W. Szejnmann, M. Umbach, Palgrave, Houndmills 2012, s. 148-165.

G. Fehl The nazi garden city, w: The garden city. Past, present and future, ed. by S.V. Ward, Spon Press, Abingdon 1992, s. 100.

27 B. Kiernan Obrazy ludobójstwa. Przegląd historyczny, przeł. J. Burzyński, w: Historia w sztuce (History in Art) [katalog wystawy], red. M.A. Potocka, Muzeum Sztuki Współczesnej, Kraków 2011, s. 86-121. 
Jako próbę zbadania stanu środowiska „po” Zagładzie można potraktować projekt artystyczny Zielnik Elżbiety Janickiej. Zielnik jest drugą po Miejscu nieparzystym pracą artystki dotyczącą tematu Zagłady. „Miejsce nieparzyste to cykl sześciu czarno-białych fotografii wywołanych na kliszach Agfy i przedstawiających powietrze nad dawnymi obozami śmierci w Auschwitz-Birkenau, Bełżcu, Chełmnie nad Nerem, Sobiborze. Treblince oraz na Majdanku. Praca ta była interpretowana przede wszystkim w kontekście dyskusji na temat granic reprezentacji Zagłady. Zielnik stanowi fotograficzną dokumentację roślin występujących na terenie byłego obozu w Treblince. O pracy tej Janicka wspominała już w 2006 roku: „Z Treblinki przywiozłam zielnik fotograficzny - bardzo starannie, metodycznie sporządzony" ${ }^{\prime 28}$. By fotografować rośliny, artystka odwiedza Treblinkę regularnie od 2004 roku. Jak mówi, praca ta z jednej strony ma na celu sporządzenie swoistej „typologii botanicznej” roślin występujących na obszarze dawnego obozu, z drugiej zaś ma stanowić pretekst do analizy „imaginarium botanicznego i zoologicznego”, na którym opierają się często dyskursy nacjonalistyczne i rasistowskie ${ }^{29}$. Fragment Zielnika został po raz pierwszy zaprezentowany w 2013 roku na wystawie Sztuka polska wobec Holokaustu zorganizowanej przez Żydowski Instytut Historyczny w Warszawie ${ }^{30}$. Na wystawie pokazano pięć analogowych, kolorowych fotografii wykonanych w 2004 roku. Przedstawiały one: Sedum Acre (rozchodnik ostry), Verbascum thapsus (dziewanna drobnokwiatowa), Thymus serpyllum (macierzanka piaskowa), Hypericum perforatum (dziurawiec zwyczajny) oraz Convolvulus arvensis (powój polny). Na zdjęciach tych, poza wymienionymi roślinami, widać zwiędłe liście, opadłe gałęzie drzew czy porastające mchem kamienie. W tym sensie mogą one przypominać „metamorfozy” Marii Sibylli Merian, której „strategię artystyczną” Natalie Zemon Davis określiła mianem „ekologicznej” ${ }^{31}$. Być może Janicka, podobnie jak Merian, bardziej od próby systematyzacji roślin zainteresowana jest transformacjami, jakim podlega świat przyrody. Porastający kamienie mech, leżące na ziemi zwiędłe liście i opadłe gałęzie drzew świadczą o tym, że natura podlega nieustannym przemianom.

28 Portrety powietrza. Z Elżbietą Janicką rozmawia Krzysztof Cichoń, "Atlas Sztuki” $2006 \mathrm{nr} 21$.

Zob. wypowiedź artystki: https://www.youtube.com/watch?v=Bvl_GtjdgEw (11.05.2017). kowska, Żydowski Instytut Historyczny, Warszawa 2013. 
Pierwsze próby klasyfikowania i opisywania roślin zostały podjęte w starożytności. W Grecji w epoce klasycznej wraz z rozwojem medycyny powstawały wykazy roślin o właściwościach leczniczych ${ }^{32}$.Zielniki (łac. herbarium) zaczęły pojawiać się w pierwszej połowie XV wieku. Ich powstawanie wiązało się z odrodzeniem botaniki, jakie nastąpiło w epoce renesansu. Początkowo herbarze były drukowanymi księgami zawierającymi opisy oraz ilustracje roślin ${ }^{33}$. Można w nich odnaleźć informacje na temat budowy, występowania, a także zastosowania poszczególnych roślin w medycynie czy magii. W porównaniu do wcześniejszych przedstawień zamieszczone w nich ilustracje były bardziej realistyczne, gdyż artyści rysowali zazwyczaj rośliny „z natury”. W pierwszej połowie XVI wieku we Włoszech pojawiły się również pierwsze „suszone" zielniki.Za ich twórcę uznaje się włoskiego medyka i botanika Luci Ghiniego, który wspólnie ze swoimi studentami zgromadził rośliny pochodzące z Włoch, Hiszpanii, Sycylii, Egiptu i Syrii34. Metoda suszenia stosowana przez Ghiniego i jego uczniów polegała na umieszczeniu rośliny między dwoma arkuszami bibuły i poddawaniu jej stopniowemu naciskowi. Następnie wysuszone rośliny przyklejano na karty papieru, które oprawiano w księgi. Każda z roślin była dokładnie opisywana. Opis zawierał informacje taksonomiczne, uwzględniał kolor i wysokość rośliny, a także dane o tym kiedy, gdzie i przez kogo została ona zebrana. Księgi te początkowo określano mianem hortus siccus („zasuszony ogród”), hortus hiemalus („ogród zimowy”) lub hortus mortus („martwy ogród”) 35. Terminu herbarium zaczęto używać na początku XVIII wieku za sprawą francuskiego botanika Josepha Pittona de Tourneforta i w tym znaczeniu został on przejęty przez Linneusza ${ }^{36}$. Od tej pory zielniki funkcjonowały przede wszystkim w formie pojedynczych kart, co ułatwiało ich wymianę oraz porównywanie roślin.

Powstawanie zielników było związane z opisanym przez Michela Foucaulta przełomem, jaki nastąpił w drugiej połowie XVII wieku. W jego wyniku doszło do rozbratu między „słowami i rzeczami”. Przedtem historia w luźny

M. Rix The Golden Age of Botanical Art, Andre Deutsch, London 2012, s. 10.

A. Zemanek Historia botaniki, w: Dzieje nauki. Nauki ścisłe i przyrodnicze, red. M. Siwiec, Wydawnictwo Szkolne PWN, Bielsko-Biała 2011, s. 405-407.

Tamże, s. 406.

Tamże. Nazwę "hortus mortus" wymienia J.R. Massey, The Herbarium, w: Vascular plant systematics, ed. by A.E. Radford et al., Harper and Row, New York 1974.

A. Arber Herbals. Their Origin and Evolution. A chapter in the History of Botany 1470-1670, Cambridge University Press, Cambridge 1953, S. 142. 
sposób łączyła ze sobą informacje na temat budowy roślin, ich właściwości leczniczych, zastosowań, a także związanych z nimi legend. Znaki, czyli wszystko to, co ludzie sądzili na temat roślin, były postrzegane jako ich nieodłączny atrybut. Nowa "historia naturalna”, która rodzi się w połowie XVII wieku, oddziela świat rzeczy od znaków. Jak pisze Foucault: „Wszelka mowa naniesiona przez czas na rzeczy zostaje zepchnięta na rubieże"37. To w wyniku owej „puryfikacji”, która odziera przedmioty z ich znaczeń, rodzi się problem reprezentacji. Nagie rzeczy zostają wyłożone na stół lub umieszczone pod mikroskopem: są mierzone, obserwowane i systematyzowane na podstawie swych zewnętrznych cech. W tym kontekście rodzą się i funkcjonują zielniki: „Dokumentami tej nowej historii nie są inne słowa, teksty bądź archiwa, ale określone przestrzenie, gdzie zestawia się rzeczy: zielniki, kolekcje, ogrody"38.

Jak wspominałem, Elżbieta Janicka, tworząc swój Zielnik, pragnie stworzyć typologię roślin występujących na terenie byłego obozu śmierci w Treblince. Jej projekt poza aspektem artystycznym ma zatem również walor dokumentacyjny. W perspektywie „długiego trwania” to właśnie roślinność rosnąca w miejscach dawnych obozów śmierci może mieć decydujące znaczenie dla ich rozpoznania. Już współcześnie szata roślinna odgrywa ważną rolę w oznaczaniu tych miejsc ${ }^{39}$. Podobnie renesansowe zielniki stanowią dziś bezcenne źródło do badań nad ewolucją roślin, ich rozprzestrzenianiem się, relacjami między ludźmi i roślinami (etnobotanika) czy zmianami klimatu.

Wspomniane powyżej nazwy używane na określenie zielników, takie jak "martwy ogród" czy „ogród zimowy”, w kontekście pracy dotyczącej Zagłady nabierają symbolicznego znaczenia. Można jednak zastanawiać się, czy Zielnik Elżbiety Janickiej rzeczywiście jest martwy. Artystka bowiem, zamiast zbierać i zasuszać rośliny, „zbiera” ich fotografie, co - jak sądzę - ma istotne znaczenie dla interpretacji jej pracy. Wydaje się, że fotografując rośliny,

37 M. Foucault Słowa i rzeczy. Archeologia nauk humanistycznych, przeł. T. Komendant, słowo/obraz terytoria, Gdańsk 2006, s. 123.

Tamże, s. 124.

Chodzi o badania prowadzone w ramach tzw. "forensic turn”. Prowadzi je m.in. C. Sturdy Colls The Archaeology of Cultural Genocide: A Forensic Turn in Holocaust Studies?, w: Mapping the „Forensic Turn": The Engagements with Materialities of Mass Death in Holocaust Studies and Beyond, ed. by Z. Dziuban, New Academic Press, Vienna 2017. Zob. także C. Sturdy Colls O tym, co minęło, lecz nie zostało zapomniane. Badania archeologiczne na terenie byłego obozu zagłady W Treblince, "Zaglada Żydów. Studia i Materialy” 2016 nr 12. Por. R. Sendyka Nie-miejsca pamięci i ich nie-ludzkie pomniki oraz E. Domańska Przestrzenie Zagłady w perspektywie ekologiczno-nekrologicznej w niniejszym numerze "Tekstów Drugich". 
artystka posługuje się medium mniej „inwazyjnym”, unikając tym samym destrukcyjnego gestu, bez którego nie jest możliwy suszony zielnik: wyrwanie rośliny wraz z korzeniami w celu jej ususzenia jest równoznaczne z jej uśmierceniem.

Drugim z założeń Zielnika jest zwrócenie uwagi na „imaginarium botaniczne", do którego często odwołują się dyskursy nacjonalistyczne. Z takiego imaginarium czerpali m.in. architekci ogrodów w czasach Trzeciej Rzeszy. W idealnym niemieckim Naturgarten miały rosnąć wyłącznie rośliny natywne, a wszelkie obce gatunki miały być z nich usuwane ${ }^{40}$. Należy również podkreślić, że w tym samym czasie, kiedy podejmowano próby klasyfikacji roślin, starano się systematyzować ludzi. Linneusz, poza opracowaniem podziału świata roślin, jako jeden z pierwszych wyróżnił rasy ludzkie na podstawie koloru skóry. Okazuje się zatem, że z pozoru niewinna czynność, jaką jest klasyfikowanie roślin, może mieć związek z dyskursem rasistowskim. W przypadku Miejsca nieparzystego, wykorzystując klisze marki AGFA, artystka wskazywała na rolę, jaką fotografia odgrywała w nazistowskiej propagandzie. Zielnik pokazuje, że systematyzowanie roślin mieści się w tym samym polu epistemologicznym (by użyć określenia Foucaulta), do którego należy wyodrębnianie ras ludzkich.

\section{Zagłada środowiska?}

Liczne studia na temat Zagłady wynikają z przeświadczenia, że zrozumienie mechanizmów, które do niej doprowadziły, pozwoli nam uniknąć podobnych wydarzeń w przyszłości. W tym sensie, jak piszą Alan Milchman i Alan Rosenberg, jest ona wydarzeniem „przekształcającym”: „Podążając za nim, możemy przystąpić do eliminacji widma ludobójczego uniwersum"41. Jak pokazał Zygmunt Bauman w Nowoczesności i Zagładzie, Zagłada stanowiła nie tyle wyrwę w historii człowieka, co raczej „naturalny” efekt nowoczesnej,

G. Fehl The nazi garden city, s. 88-106. Na temat stosunku nazistów do przyrody zob. np. How Green Were the Nazis? Nature, Environment and Nation in the Third Reich, ed. by F.-J. Brüggemeier, M. Cioc, T. Zeller, Ohio University Press, Athens, OH 2005; T. Lekan Imagining the Nation in Nature: Landscape Preservation and German Identity 1885-1945, Harvard University Press, Cambridge, MA 2004. O tzw. ekologii nazistowskiej pisał też L. Ferry Nowy ład ekologiczny. Drzewo, zwierzę i człowiek, przeł. H. Miś, A. Miś, Centrum Uniwersalizmu przy UW, Polski Oddział Międzynarodowego Towarzystwa Uniwersalizmu, Warszawa 1995.

41 A. Milchman, A. Rosenberg Eksperymenty w myśleniu o Holocauście. Auschwitz, nowoczesność i filozofia, przeł. L. Krowicki, J. Szacki, Scholar, Warszawa 2003, s. 159. 
zracjonalizowanej i zbiurokratyzowanej kultury ${ }^{42}$. Z kolei Giorgio Agamben w pracach z cyklu Homo Sacer dowiódł, że figura „muzułmana”, więźnia obozu koncentracyjnego, doprowadzonego do kresu człowieczeństwa, stanowi tylko jedną z figuracji „nagiego życia" “3. Czy wiedza na temat Zagłady może zwiększyć nie tylko naszą świadomość na temat różnego rodzaju wykluczenia społecznego, lecz także zagrożeń wynikających z instrumentalnej postawy człowieka wobec przyrody? Kwestię tę podejmuje John K. Roth w artykule The World Around Us: What Have We Learned from the Holocaust? [Świat dookoła nas. Czego nauczyliśmy się z Holokaustu?], który otwiera wydany w 2013 roku zbiór artykułów Holocaust and Nature. Roth zastanawia się w nim nad związkami między przemocą, jaką człowiek zadaje drugiemu człowiekowi, i jego stosunkiem do przyrody ${ }^{44}$. Didier Pollefeyt, redaktor tomu, skomentował te rozważania w następujący sposób:

Chociaż Holocaust nie mieścił się w ludzkiej wyobraźni, wydarzyła się katastrofa. Niemożliwe stało się możliwe. Biorąc pod uwagę katastrofalne perspektywy związane z przyszłością systemu ekologicznego zwanego „ziemią", również często myślimy, że niemożliwe nie jest możliwe. Relatywizujemy zagrożenia ekologiczne, pocieszając się, że sytuacja nie jest taka zła, jak sądzimy, że sami nie dostrzegamy lub nie doświadczamy rozkładu natury, że przesadzamy. Natura jest tak samo narażona na zło i destrukcję, jak nasze międzyludzkie relacje. ${ }^{45}$

Podobnie Eric Katz w artykule Nature's Healing Power, the Holocaust and the Environmental Crisis zakłada, że istnieją związki między Zagładą i destrukcją środowiska: „Ludobójstwo i ekobójstwo mogą zostać połączone poprzez analizę pojęcia dominacji. Porównawcze studia tych dwóch rodzajów zła mogą poprowadzić nas w stronę rozwinięcia harmonijnych relacji zarówno ze światem naturalnym, jak i innymi istotami ludzkimi" ${ }^{\prime 46}$. Diagnozy te nabierają

Z. Bauman Nowoczesność i Zagłada, przeł. T. Kunz, Wydawnictwo Literackie, Kraków 2009.

G. Agamben Homo Sacer. Suwerenna władza i nagie życie, przeł. M. Salwa, Próczyński i S-ka, Warszawa 2008.

J.K. Roth The World Around Us: What Have We Learned from the Holocaust?, w: Holocaust and Nature, ed. by D. Pollefeyt, Lit Verlag, Zürich 2013, s. 14-22.

D. Pollefeyt, In Response to /ohn K. Roth, w: Holocaust and Nature, s. 23.

E. Katz Nature's Healing Power, the Holocaust, and the Environmental Crisis, w: Judaism and Environmental Ethics. A Reader, ed. By M.D. Yaffe, Lexington Books, Landbam 2001, s. 310. Jak 
znaczenia, jeśli weźmie się pod uwagę fakt, że - jak przekonuje Timothy Snyder - aktualna sytuacja geopolityczna przypomina tę sprzed II wojny światowej. „Zmiana klimatu - pisze autor Czarnej ziemi - jako problem lokalny może poskutkować lokalnymi konfliktami, natomiast jako kryzys globalny, może stworzyć zapotrzebowanie na globalne ofiary"47.

Przyjęcie perspektywy historii środowiskowej otwiera pole do dalszych, szczegółowych studiów, które umożliwią bliższe zbadanie relacji zachodzących między środowiskiem a Zagładą w różnych wymiarach. Pozwala również przeorientować pole badawcze i wykroczyć poza dyskusje na temat możliwości reprezentacji Zagłady. Pojęcie antropocenu wyznacza nową perspektywę czasową i zachęca do badania długotrwałych skutków Zagłady. Mając na uwadze toczące się aktualnie dyskusje na temat powodowanych działalnością człowieka zmian klimatu, wymierania gatunków, wojen klimatycznych, klęsk ekologicznych itp., otwarcie się studiów nad Zagładą na historię środowiskową ma wymiar nie tylko epistemiczny, lecz również krytyczny. Zrozumienie związków między Zagładą i środowiskiem może bowiem przyczynić się do rozpoznania współczesnych zagrożeń wynikających z instrumentalnej, opartej na instrumentalnej relacji człowieka do przyrody i uniknięcia kolejnych katastrof.

zauważa Marta Tomczok, w latach 80. XX wieku również w polskiej prozie dotyczącej Zagłady można zaobserwować pojawienie się wątku zmian klimatycznych i degradacji środowiska. M. Tomczok Klimat Zagłady (w perspektywie powieści Pawła Huellego, Tadeusza Konwickiego, Andrzeja Kuśniewicza i Piotra Szewca), w niniejszym numerze "Tekstów Drugich".

47 T. Snyder Czarna ziemia..., s. 418. 


\section{Abstract}

\section{Jacek Małczyński}

UNIVERSITY OF WROCŁAW

An Environmental History of the Holocaust

Małczyński suggests to take the comparison of the Holocaust to an earthquake literally in the context of debates on the anthropocene as a new epoch in the history of the Earth. He argues that Holocaust Studies should embrace environmental history, which examines the relationship between human an non-human factors (such as the shaping of landscapes, the climate, weather, plants and animals) in the environment. This, Małczyński argues, would allow Holocaust scholars to enter the debate on climate change, the extinction of species, climate wars and migrations caused by global warming.

\section{Keywords}

Holocaust, environmental history, anthropocene 